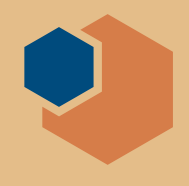

\section{Universities prepare next-generation workforce to benefit from the Materials Genome Initiative}

\author{
www.whitehouse.gov/mgi
}

T The US government's Materials Genome Initiative (MGI), now in its third year, aims to significantly reduce the time and cost to bring new materials from the laboratory to the marketplace. Achieving this goal not only requires greater integration of experiment, computation, and digital data, but also a new generation of scientists and engineers with the necessary skills and cultural mind-set to think predictively about materials design and work in interdisciplinary teams.

Previously the University Materials Council, which comprises senior representatives from more than 100 materials science academic programs in the United States and Canada, pledged to enact educational reforms in pursuit of MGI in a July 2011 letter to President Obama. A set of materials education principles released a year later committed to equipping students with the computational, experimental, and informatics skills necessary to accomplish the goals of MGI, and to integrate these skills with traditional elements of the field. It also emphasized including industry in setting educational goals.

Academic departments are already making some headway in educational reform. In June, on the second anniversary of MGI, the White House Office of Science and Technology Policy (OSTP) announced several new university efforts comprising degree programs, facilities, and teaching tools. For example, Lehigh University's Materials Science and Engineering Department is creating new teaching facilities that will give students hands-on experience in integrated experiment and computation. To help equip students with simulation and modeling skills, Johns Hopkins University is releasing computational materials teach- ing modules developed and tested in its undergraduate courses.

Other universities announced new courses, certificates, and degree programs. The Massachusetts Institute of Technology is addressing the innovation and commercialization aspects relevant to MGI through a new 13-week massive open online course, or MOOC, being offered this fall. The Georgia Institute of Technology is developing a new graduate certificate program in computational materials and big data, while North Carolina State University (NCSU) will offer a new online Master's in Nanoengineering degree beginning this fall.

The development of NCSU's Master's program has been a multidisciplinary effort across several engineerrequires the integration of computation and experiment, but also the integration of many disciplines. We wanted multiple departments involved in our degree because MGI requires more than just traditional materials science knowledge," said Justin Schwartz, department head of Materials Science and Engineering. There are many advantages to offering online courses, certificates, and degrees. "Distance education allows you to reach a broader community," Schwartz said. "It's easier for both employees and employers because employees can take classes at their work site, meaning minimal time away from the office, and it can be viewed as a work activity."

Other universities have already implemented new course offerings, spurred in part by the advent of Integrated Computational Materials Engineering. For example, the University of Michigan offers a summer school that provides an introduction to the theory, practice, and pedagogy of advanced computational ing and science departments. "MGI
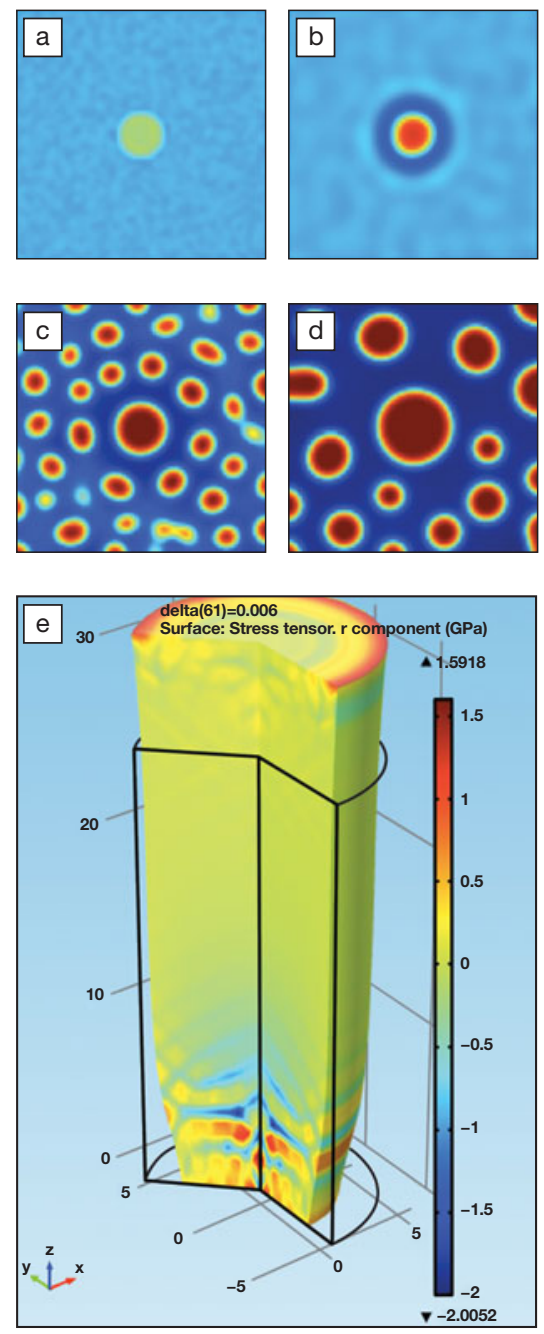

(a-d) A series of images from a simulation of spinodal decomposition, nucleation, growth, and coarsening was incorporated into a class on kinetics and phase transformations in materials science and engineering using the COMSOL software. (e) An image from a COMSOL simulation of plastic necking was incorporated into a class on the mechanical properties of materials. Images courtesy of Michael Falk, Johns Hopkins University.

techniques, while Purdue University has recently begun offering an online course in predictive theory and simulation.

These types of curriculum changes are in line with a consensus that predictive materials design, a key component of MGI, increasingly depends on computational methods - a topic not traditionally emphasized in US materials science curricula. A report from a MGI-focused workshop, held at the National Science Foundation in December 2012, made several recommendations regarding 
workforce training. At the undergraduate level, it called for increased computational instruction aimed at accelerating the introduction of new materials into engineering use. At the graduate, postdoctoral, and faculty level, it recommended instruction both in computational content and pedagogy for experimentalists, and education in experimental tools that complement simulation for computationalists. It also noted that online education can be particularly valuable as it allows flexibility in both pace and timing.

In addition to reforms universities are undertaking, OSTP is engaging in outreach efforts to boost public knowledge of and enthusiasm for materials science. Earlier this summer, the White House held a virtual event on materials science as part of its "We the Geeks" series, designed to highlight the future of science, technology, and innovation on a range of topics. The event featured talks on "The Stuff Superheroes Are Made Of," including stealth technology, liquid armor, and self-healing materials. These virtual events, using the Google+ Hangout platform, featured live video streaming and real-time audience questions. The events are archived on the White House YouTube video channel. OSTP is also liaising with the Smithsonian Associates, the Institution's cultural and educational division, to organize a free public event this fall in Washington, $\mathrm{DC}$, on the evolution of advanced materials and the potential they hold for new cutting-edge applications.
Enduring educational reform takes time, however. Challenges include ensuring any curricular changes meet accreditation requirements and having a critical mass of faculty with the expertise to design and teach computational techniques. According to Schwartz, some departments are still reluctant to commit to hiring more computational faculty until the government's intent for a substantial and sustained federal investment becomes clearer. Regardless of the federal budget climate, however, materials science and engineering in the United States is shifting toward an integrated computational and experimental approach, and associated educational reforms appear inevitable.

Ashley A. White
EU and industry join forces to invest $€ 22$ billion in research and innovation http://ec.europa.eu/research/jti/index_en.cfm

$\mathbf{T}$ he European Commission, European Union (EU) Member States, and European industry will invest more than $€ 22$ billion over the next seven years in innovation. Most of the investment will go to five public-private partnerships in innovative medicines, aeronautics, bio-based industries, fuel cells and hydrogen, and electronics. These research partnerships are designed to find solutions to major challenges for society that are not being solved quickly enough by the market alone, such as reducing carbon emissions.

Overall, a proposed $€ 8$ billion investment from the next EU research and innovation program, Horizon 2020, will secure around $€ 10$ billion from industry, and close to $€ 4$ billion from EU Member States.

European Commissioner for Research, Innovation and Science Máire Geoghegan-Quinn said, "Working together will enable us to tackle issues that no one company or country can deal with alone."

The five Public-Private Partnerships, called "Joint Technology Initiatives" (JTIs), are:

- Fuel Cells and Hydrogen 2, to expand the use of clean and efficient technologies in transport, industry, and energy;

- Clean Sky 2, to develop cleaner, quieter aircraft with significantly less $\mathrm{CO}_{2}$ emissions;

- Electronic Components and Systems, to boost Europe's electronics manufacturing capabilities;

- Bio-based Industries, to use renewable natural resources and innovative technologies for greener everyday products; and

- Innovative Medicines 2, to develop next-generation vaccines, medicines, and treatments, such as new antibiotics.

The Innovative Medicines Initiative, Clean Sky, and Fuel Cells and Hydrogen JTIs all currently exist, while the Electronics JTI will combine two current partnerships. The Bio-based Industries JTI is a new initiative. All five will issue open calls for proposals.

The second phase of the Fuel Cells and Hydrogen JTI is expected to start in 2014 and run for 10 years. The goals of this initiative are to reduce the cost of fuel-cell systems for transportation by a factor of 10; increase the electrical effi- ciency of fuel cells for power production by $10 \%$; and demonstrate the viability of large-scale hydrogen production from electricity generated from renewable energy sources.

The purpose of the Clean Sky JTI is to increase aircraft fuel efficiency, thus reducing $\mathrm{CO}_{2}$ emissions by $20-30 \%$; and to reduce aircraft $\mathrm{NOx}$ and noise emissions by $20-30 \%$ compared to "state-of-the-art" aircraft entering into service as of 2014. This JTI is planned for 2014-2024.

Combining the ARTEMIS embedded computing systems initiative and the nanoelectronics JTI set up 2008, the Electronic Components and Systems JTI will advance Europe's capability and capacity to design and manufacture stateof-the-art electronic components and systems. This JTI involves partnerships, in particular, with industry in the areas of micro-/nanoelectronics, smart integrated systems, and embedded/cyber-physical systems. The JTI will begin in 2014 and will be fully operational up to 2020 , followed by a running down phase to 2024 .

The Bio-based Industries JTI will focus on feedstock, biorefineries, and the bio-related product market. This JTI is expected to start in 2014 and end in 2020. 